\title{
A comparative study of the flux and fate of the Mississippi and Yangtze river sediments
}

\author{
KEHUI XU ${ }^{1,2} \&$ S.L. YANG ${ }^{3}$ \\ 1 Department of Oceanography and Coastal Sciences, Louisiana State University, Baton Rouge, Louisiana 70803, USA \\ $\underline{\mathrm{kxu} @ \text {,1su.edu }}$ \\ 2 Coastal Studies Institute, Louisiana State University, Baton Rouge, Louisiana 70803, USA \\ 3 State Key Lab of Estuarine and Coastal Research, East China Normal University, Shanghai 200062 China,
}

\begin{abstract}
Large rivers play a key role in delivering water and sediment into the global oceans. Large-river deltas and associated coastlines are important interfaces for material fluxes that have a global impact on marine processes. In this study, we compare water and sediment discharge from Mississippi and Yangtze rivers by assessing: (1) temporal variation under varying climatic and anthropogenic impacts, (2) delta response of the declining sediment discharge, and (3) deltaic lobe switching and Holocene sediment dispersal patterns on the adjacent continental shelves. Dam constructions have decreased both rivers' sediment discharge significantly, leading to shoreline retreat along the coast. The sediment dispersal of the river-dominated Mississippi Delta is localized but for the tide-dominated Yangtze Delta is more diffuse and influenced by longshore currents. Sediment declines and relative sea level rises have led to coastal erosion, endangering the coasts of both rivers.
\end{abstract}

Key words Mississippi River; Yangtze River; water discharge; sediment transport; dam construction

\section{INTRODUCTION}

Large rivers play a key role in delivering water and sediment to oceans (Milliman \& Meade, 1983; Milliman \& Syvitski, 1992; Milliman \& Farnsworth, 2011). Large river deltas and associated coastlines are important interfaces between continents and oceans for material fluxes that have a global impact on marine processes (Bianchi \& Allison, 2009). The transport of water and sediment, however, is controlled by climatic, fluvial, geomorphological, anthropogenic and other processes. These processes may interact in space and time, making it challenging to quantify water and sediment fluxes. During the past half century, the global river systems have been greatly impacted by humans (Vörösmarty et al., 2003). More than half the world's large river systems are affected by dam construction and water diversion (Nilsson et al., 2005; Syvitski et al., 2005).

The Mississippi and Yangtze (Fig. 1) are the largest rivers in North America and Asia, respectively. Their geological and hydrological conditions and geomorphological evolution have previously been reported for the Mississippi River (Meade et al., 1995; Colman et al., 1998; Roberts, 1998; Day et al., 2007; Bianchi \& Allison, 2009; Blum \& Roberts, 2009; Horowitz, 2009; Meade \& Moody, 2010; Allison et al., 2012) and the Yangtze River (Chen et al., 2001; Yang et al., 2002; Xu et al., 2006; Yang et al., 2006; Xu \& Milliman, 2009; Xu et al., 2009; Yang et al., 2011). However, only a few papers have directly compared these two rivers (Xu et al., 2007; Bianchi \& Allison, 2009). In this study, water and sediment discharges from the Mississippi and Yangtze rivers are compared. This study has scientific, social and economic relevance to both the Unites States and China.

\section{WATER AND SEDIMENT DISCHARGE}

\section{The Mississippi River}

The Mississippi is the largest river in North America and drains $41 \%$ of the continental United States (Fig. 1). The Mississippi used to annually deliver $580 \mathrm{~km}^{3}$ of water (6th largest in the world) and $210 \mathrm{Mt}$ (million tonnes) of sediment (7th largest) into the Gulf of Mexico (Milliman \& Meade, 1983). Western Missouri and Arkansas tributaries have low runoff but high sediment yield across the northern Great Plains and Rocky Mountains. In contrast, the eastern Ohio tributary has high runoff but relatively low sediment yields (Figs 1 and 2). More than 50000 dams were constructed in the Mississippi basin during the past century (Syvitski \& Milliman, 2007). Since the 1930s, dam 

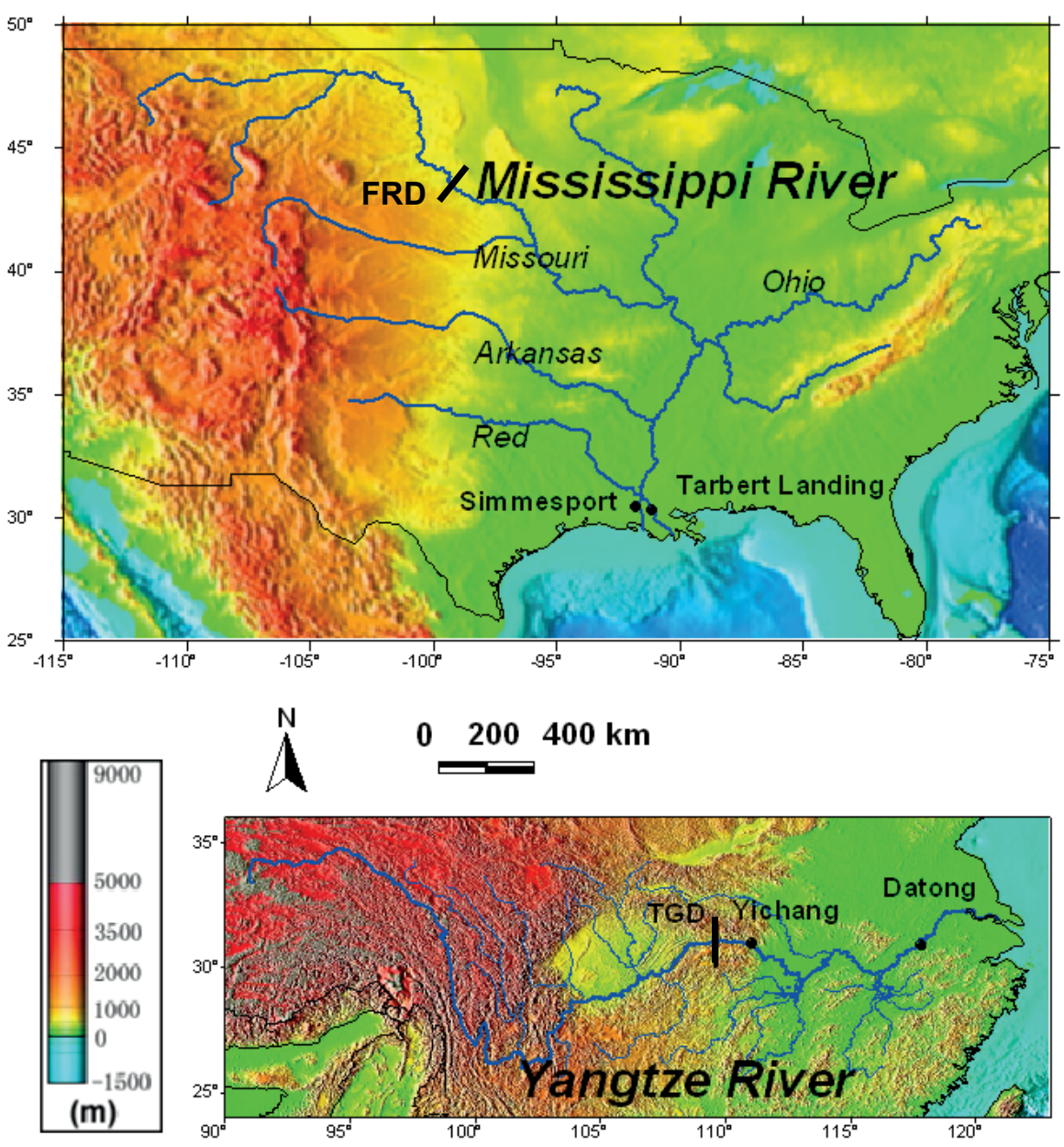

Fig. 1 The Mississippi and Yangtze River basins. Topographic maps are from NOAA ETOPO2 web site (http://www.ngdc.noaa.gov/). Fort Randall Dam (FRD); Three Gorges Dam (TGD).

construction has been accelerated to improve navigation and better manage flood and hydropower. In spite of reservoir impoundments, water discharge of the Mississippi has not decreased. In fact, between 1950 and 2000, water discharge increased by $\sim 30 \%$ due to the Pacific Decadal Oscillation and the North Atlantic Oscillation (Fig. 3; Hurrell, 1997). Despite the increased water discharge, sediment discharge of the Mississippi has decreased by over $50 \%$ since the early 1950 s due to impoundments and other engineering activities, such as meander cut-offs, bank revetments and soil erosion controls (Fig. 3; Meade \& Moody, 2010). The declining sediment discharge is mainly related to construction of the Fort Randall (Fig. 1) and Gavins Point dams in 1953 and the Garrison Dam in 1954 along the Missouri River. Sediment delivery since the 1960s has only slightly declined although new dams have been built (Fig. 3). The Missouri River was the major sediment supplier to lower reaches of the Mississippi and the contributions from the Arkansas, Ohio and Red rivers were smaller (Fig. 4).

\section{The Yangtze River}

Originating in the Tibetan Plateau (Fig. 1), the Yangtze River (Changjiang) historically discharged $900 \mathrm{~km}^{3}$ of water (4th largest in the world) and $480 \mathrm{Mt}$ of sediment (4th largest) annually into the East China Sea (Milliman \& Syvitski, 1992). These values are significantly higher than those of the Mississippi although the Yangtze basin area is only $56 \%$ of the Mississippi basin (Fig. 1; Table 1). Water and sediment discharge from tributaries of the Yangtze vary considerably. The western and northern tributaries have low runoff but high sediment yield, while the southeast 

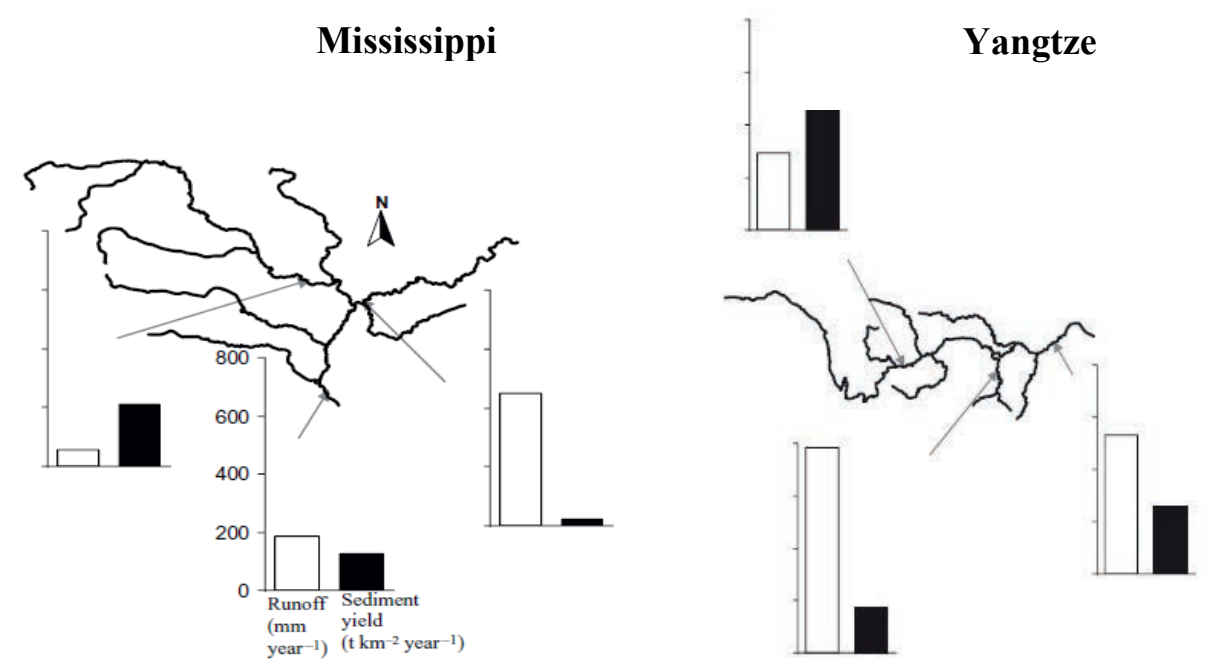

Fig. 2 Spatial variations of runoff (mm/year) and sediment yield $\left(\mathrm{t} / \mathrm{km}^{2} /\right.$ year) in the Mississippi and Yangtze basins (modified after Xu et al., 2007).

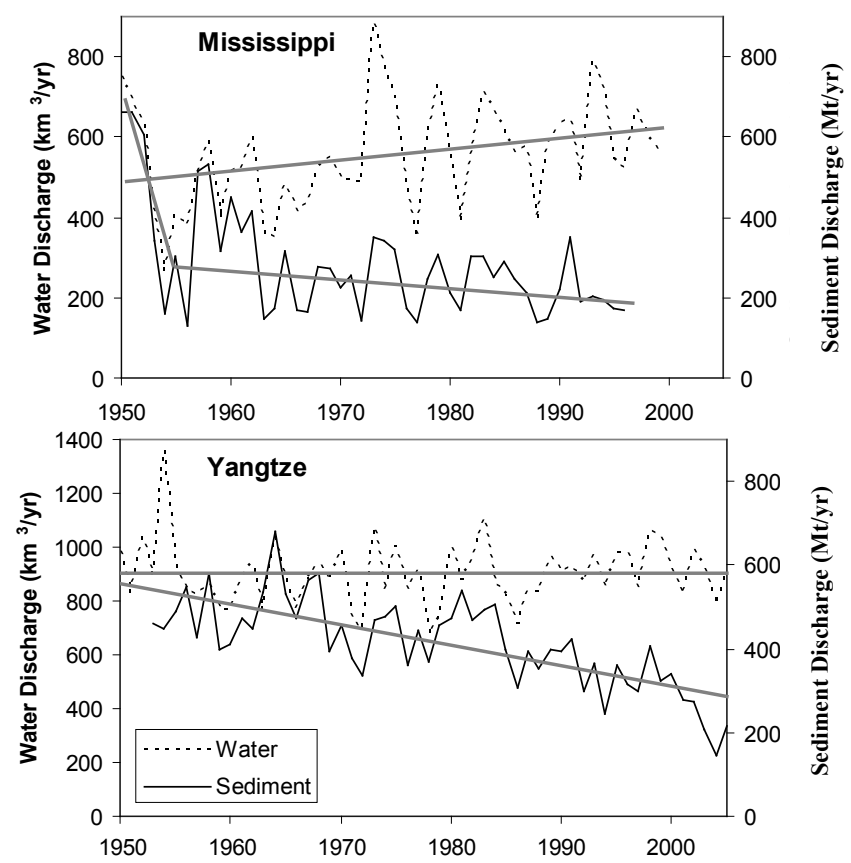

Fig. 3 Temporal variation of water and sediment discharge in the Mississippi (at Tarbert Landing) and Yangtze (at Datong) basins (from Xu et al., 2007). See Fig. 1 for locations of gauging stations.

Table 1 The comparison of the Mississippi and Yangtze rivers.

\begin{tabular}{|c|c|c|c|c|c|c|c|}
\hline \multirow[t]{2}{*}{ River } & \multirow{2}{*}{$\begin{array}{l}\text { Area } \\
\left(1000 \mathrm{~km}^{2}\right)\end{array}$} & \multirow{2}{*}{$\begin{array}{l}\text { Runoff } \\
\text { (mm/year) }\end{array}$} & \multirow{2}{*}{$\begin{array}{l}\text { Sed. Yield } \\
\left(\mathrm{t} / \mathrm{km}^{2} / \text { year }\right)\end{array}$} & \multicolumn{2}{|c|}{ Water discharge $\left(\mathrm{km}^{3} /\right.$ year $)$} & \multicolumn{2}{|c|}{ Sed. Discharge (Mt/year) } \\
\hline & & & & Pre-dam & Post-dam & Pre-dam & Post-dam \\
\hline Mississippi & 3300 & 490 & 120 & $\begin{array}{l}490 \\
(1950-1953)\end{array}$ & $\begin{array}{l}510 \\
(2000-2010)\end{array}$ & $\begin{array}{l}600 \\
(1950-1953)\end{array}$ & $\begin{array}{l}200 \\
(2000-2010)\end{array}$ \\
\hline Yangtze & 1800 & 500 & 260 & $\begin{array}{l}900 \\
(1953-1963)\end{array}$ & $\begin{array}{l}860 \\
(2000-2010)\end{array}$ & $\begin{array}{l}480 \\
(1953-1963)\end{array}$ & $\begin{array}{l}180 \\
(2000-2010)\end{array}$ \\
\hline
\end{tabular}

Date source: Milliman \& Farnsworth (2011) and others.

tributaries indicate high runoff but low sediment yield (Fig. 2). The major sediment supply is from the mountains and gullied tributaries upstream of the Yichang gauging station (Figs. 1 and 5) as well as from highly-erodible loess deposits in northern tributaries (Xu et al., 2007). 


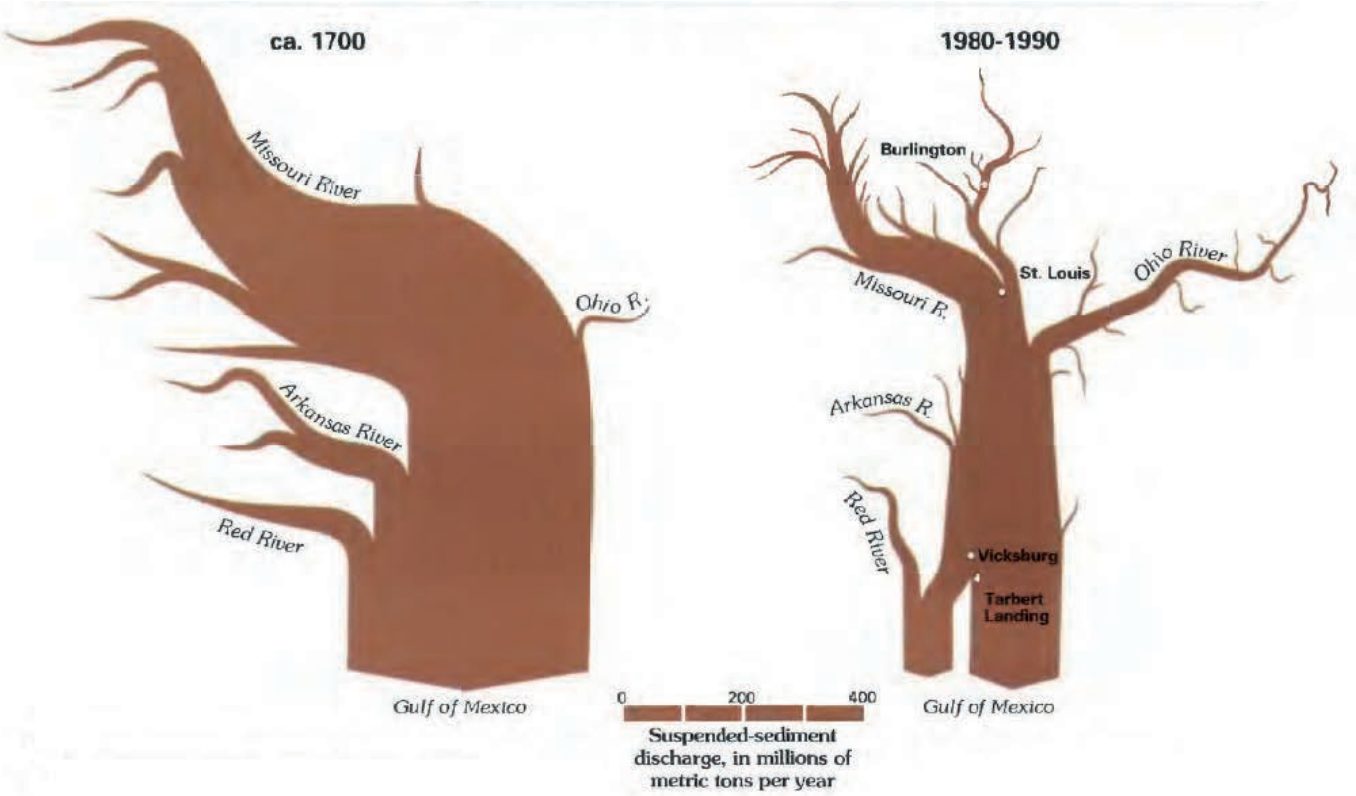

Fig. 4 Spatial and temporal variation of Mississippi sediment discharge (Meade et al., 1995).

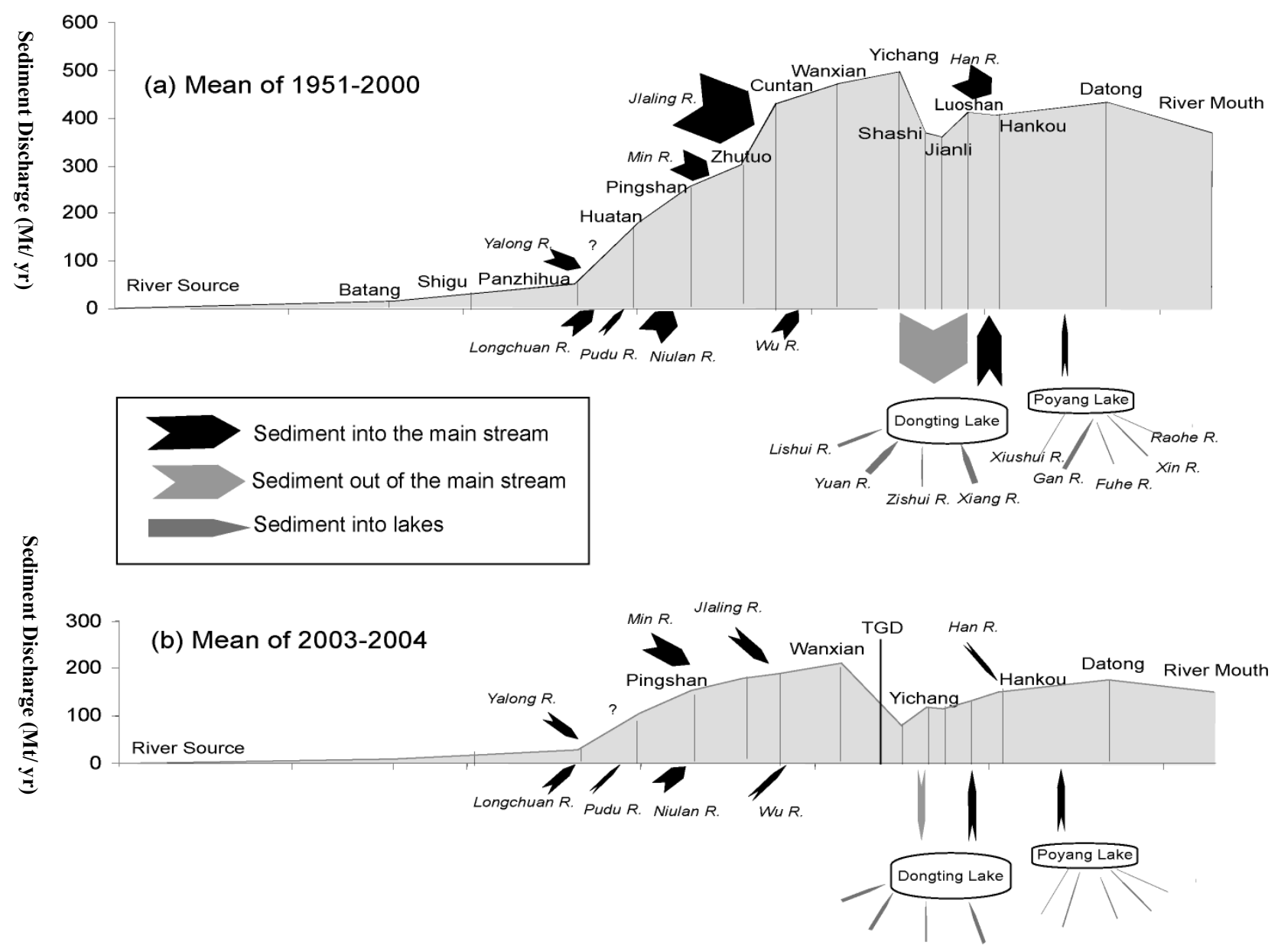

Fig. 5 Spatial and temporal variation of Yangtze sediment discharge. Locations of TGD, Yichang and Datong are shown in Fig. 1. Note the active sediment fluxes between two lakes (Dongting and Poyang) and the Yangtze mainstem. 
Since 1950, $50 \%$ of the world's largest dams have been built in China (Fuggle \& Smith, 2000) and many of these are located in the Yangtze basin. Currently, $>50000$ dams are located in the Yangtze basin which is comparable to the Mississippi. Because the total reservoir storage capacity over the past 60 years is only about $200 \mathrm{~km}^{3}$ or $22 \%$ of the Yangtze annual runoff (Yang et al., 2005), the Yangtze annual water discharge has changed very little (Fig. 3) (Yang et al., 2010). Dam construction, soil-conservation and decline of precipitation in the high-sediment-yield Yangtze upstream have decreased the Yangtze sediment discharge from $480 \mathrm{Mt} / \mathrm{year}$ (1953-1963) to about $150 \mathrm{Mt} /$ year in recent years (Xu et al., 2006; Yang et al., 2011). In contrast to a sharp decline in sediment production in the Mississippi (Fig. 3), the decrease in the Yangtze has been more gradual (Fig. 3) because major dams were phased in over time and no large dam was built on the mainstem before 2003. The Three Gorges Dam (TGD) (Fig. 1) built in 2003 was the first large dam on the Yangtze mainstem. Four new large dams on the Jinshajiang River, the main sediment source of the Yangtze River, will add an additional $41 \mathrm{~km}^{3}$ of total water-storage capacity (compared with $39 \mathrm{~km}^{3}$ of TGD). Accordingly, these dams will decrease sediment discharge of the Yangtze further to approx. $110 \mathrm{Mt} /$ year in the next several decades (Yang et al., 2014).

\section{EVOLUTION OF DELTAIC COASTS}

Due to river forcing and relatively low energy of waves and tides (tidal range $0.3 \mathrm{~m}$ ), the Mississippi Delta has a "bird-foot" shaped morphology and highly localized sediment accumulation (Coleman et al., 1998a). During the past 4600 years, the Mississippi has created six major delta complexes (Fig. 6; Day et al., 2007). These large-scale deltaic morphological changes resulted from changes in slope and spaces available for sediment accumulation, which were influenced by sea level change and tectonics uplift/subsidence. In contrast, the Yangtze estuary is a tide-dominated system (spring tidal range $3.8 \mathrm{~m}$ ) with a funnel-shaped geometry. During the past 7000 years, due to the effects of deforestation and agriculture on sediment supply in the Yangtze basin, sand bars at the river mouth have steadily shifted to the southeast, causing the shorelines to prograde southeastward (Fig. 6) (Hori et al., 2001).

\section{SEDIMENT DISPERSAL IN THE COASTAL OCEAN}

Patterns of sediment dispersal near the modern Mississippi bird-foot delta are mainly associated with river plume dynamics, mass wasting processes and hurricane/storm events. Based on bottomboundary layer observations about $100 \mathrm{~km}$ west of the Mississippi Delta, Wright et al. (1997) found that near-bed flows were very weak and the combined wave-current shear stress was insufficient to transport suspended sediment under fair-weather conditions. Coleman et al. (1998b) reported extensive mass wasting processes (slumping, mud slides) on the Mississippi delta front and Walsh et al. (2006) found geophysical evidence of mudflow near the Mississippi subaqueous delta after hurricanes Katrina and Rita in 2005. These studies highlight the importance of storm remobilization and gravity-driven transport in these subaqueous regions. Using short-lived radionuclides, Corbett et al. (2004) showed that river-borne sediment was transported less than $\sim 30 \mathrm{~km}$ from the river mouth before initial deposition. However, seasonal variation in ${ }^{7} \mathrm{Be}$ and ${ }^{137} \mathrm{Cs}$ suggest that significant remobilization and potential export of sediment out of the Mississippi subaqueous delta occurs during high-energy winter months. Because the river sediment supply is much larger than the redistribution by oceanographic processes, most of Mississippi sediment deposits near the river outlets and the depocenters are near historical and modern Mississippi deltas (Fig. 7).

The Yangtze River flows onto a wide and gentle epicontinental shelf of the East China Sea and forms a 1000-km long mud wedge. Based on ${ }^{210} \mathrm{~Pb}$ data (DeMaster et al., 1985; Alexander et al., 1991; Huh \& Su, 1999; Liu et al., 2006, 2007), 100-year time scale sediment accumulation rates generally exceed $1 \mathrm{~cm} /$ year near the river mouth, and decrease towards the Taiwan Strait. These 100-year time scale accumulation rates, however, are much smaller than 100-day time scale rates determined using the ${ }^{234} \mathrm{Th}$ method $(4.4 \mathrm{~cm} /$ month in summer near the river mouth; DeMaster et al., 1985). These data suggest that delivery and transport of the Yangtze sediment are 

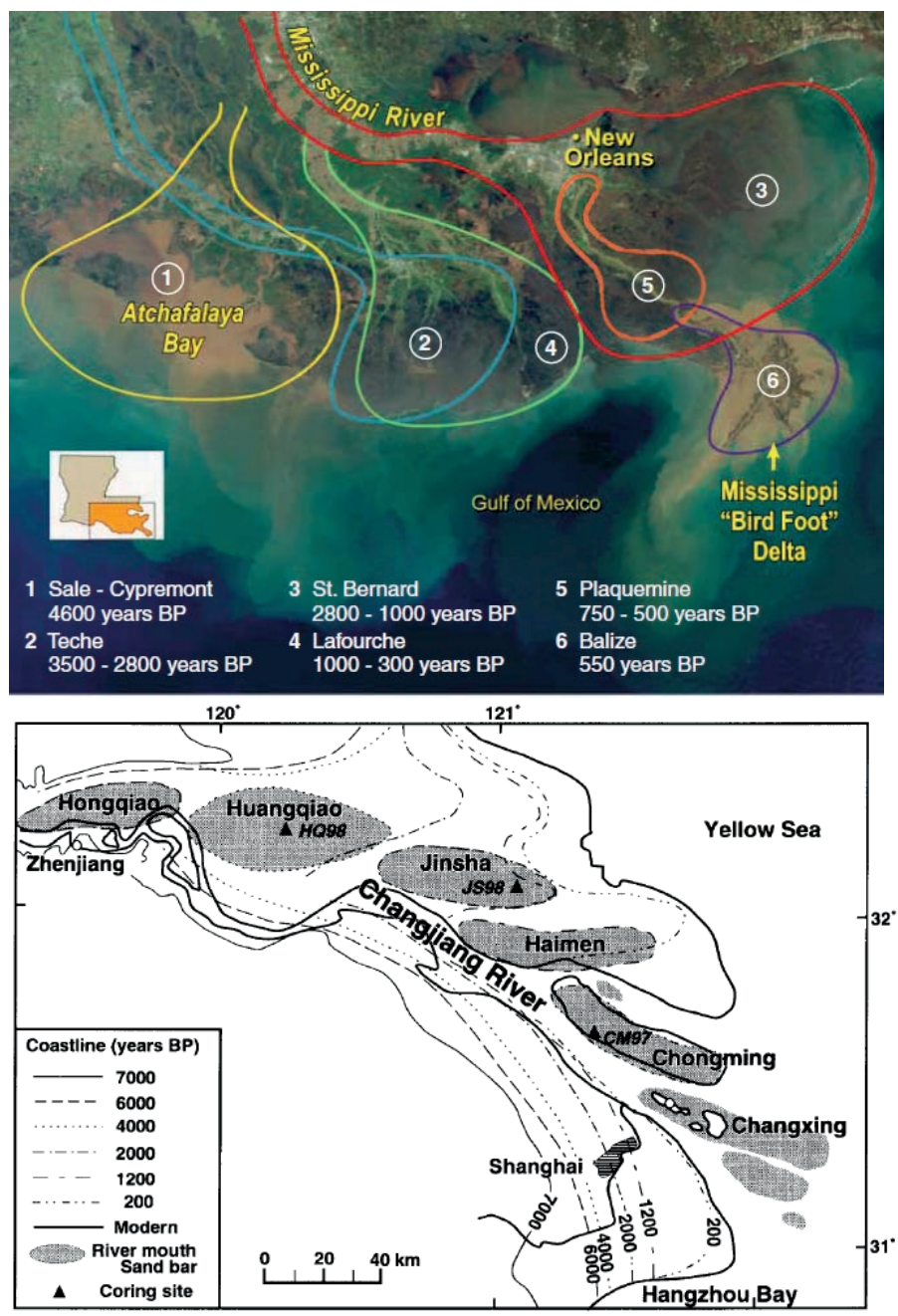

Fig. 6 Top, Mississippi deltaic lobe switching during the past 5000 years (Day et al., 2007); Bottom, shoreline evolution and shifting of sand bar of the Yangtze estuary (Hori et al., 2001).

decoupled. The Yangtze River deposits most of its sediment during the summer when the longshore current is weak. During energetic late autumn-early spring storms, most of the summer sediment is re-suspended and transported southward by energetic longshore currents (Xu et al., 2012). As a result, an elongated mud belt was formed by tidal re-suspension and longshore transport on the inner shelf of the East China Sea during the past 10000 years (Fig. 7; Xu et al., 2012).

\section{COASTAL CHANGES}

Wetlands in Louisiana are considered as the most biologically-diverse ecosystems, serving as home for numerous plants and animals. These wetlands, however, are in peril because Louisiana currently undergoes about $90 \%$ of the nation's coastal wetland loss. Since the 1930s coastal Louisiana has lost over $4660 \mathrm{~km}^{2}$ of land, diminishing wetland habitats, increasing flood risk, and endangering the coastal environment. This land loss is primarily associated with decreased sediment discharge from the Mississippi and Atchafalaya rivers, relative sea level rising, levee construction, sediment compaction, withdrawals of water, oil and gas, as well as other natural and human activities (Day et al., 2007; Törnqvist et al., 2008; Blum \& Roberts, 2009). In 2012 the Louisiana Coastal Protect \& Restoration Authority (CPRA) issued Louisiana's Comprehensive Master Plan for a Sustainable Coast, and two key restoration tools promoted by CPRA are the marsh creation and sediment diversion. A significant amount of water and sediment will be diverted from the mainstem of the Mississippi River to multiple receiving basins to build new land or slow down coastal erosion. 

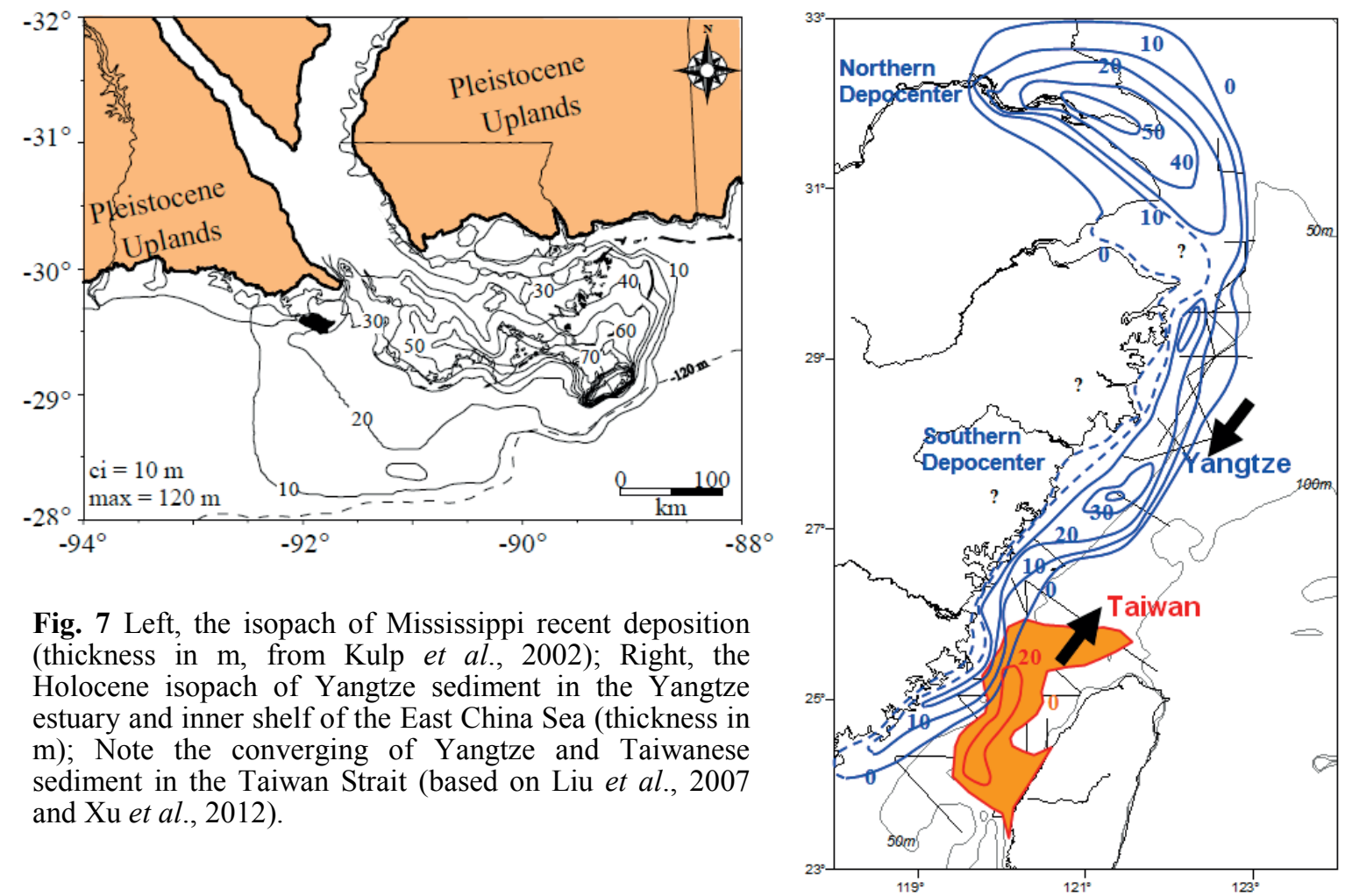

Fig. 7 Left, the isopach of Mississippi recent deposition (thickness in $\mathrm{m}$, from Kulp et al., 2002); Right, the Holocene isopach of Yangtze sediment in the Yangtze estuary and inner shelf of the East China Sea (thickness in $\mathrm{m})$; Note the converging of Yangtze and Taiwanese sediment in the Taiwan Strait (based on Liu et al., 2007 and $\mathrm{Xu}$ et al., 2012).

Along with the decline in sediment supply from the Yangtze River, the total progradation rate of the tidal wetland in the delta front has decreased by $70 \%$, and local erosion has been found (Yang et al., 2005). Meanwhile, reclamation of tidal wetland has been accelerated in the Yangtze Delta in recent decades. For example, $1100 \mathrm{~km}^{2}$ of tidal wetland has been embanked in Shanghai since the $1950 \mathrm{~s}$, which is $25 \%$ of the cumulative reclamation during the past 2000 years, and is now $15 \%$ of the total area of Shanghai. As a result, tidal wetland has disappeared in many places such as the southern bank of the estuary and the eastern coast of the Hengsha Island. To speed up progradation, coastal concrete structures have been built along the delta coasts. The major objective of this practice is for reclamation but not for the recovery of tidal wetland. In future decades, the sediment discharge of the Yangtze River will further decrease to $\sim 110 \mathrm{Mt} /$ year due to construction of four large cascade reservoirs (Yang et al., 2014). This will threaten the delta coast, and comprehensive measures for coastal protection and tidal wetland conservation/revival are needed.

Acknowledgements This study was funded by the Natural Science Foundation of China (NSFC) (41130856). Dr Mike Stone provided valuable comments and suggestions to improve this manuscript.

\section{REFERENCES}

Alexander, C.R., DeMaster, D.J. \& Nittrouer, C.A. (1991) Sediment accumulation in a modern epicontinental-shelf setting: The Yellow Sea. Marine Geol. 98(1), 51-72.

Allison, M. et al. (2012) A water and sediment budget for the lower Mississippi-Atchafalaya River in flood years 20082010: Implications for sediment discharge to the oceans and coastal restoration in Louisiana. J. of Hydrol. 432$433,84-97$.

Bianchi, T.S. \& Allison, M.A. (2009) Large-river delta-front estuaries as natural "recorders" of global environmental change. Proc. of the National Academy of Sci. 106(20), 8085-8092.

Blum M.D. \& Roberts H.H (2009) Drowning of the Mississippi Delta due to insufficient sediment supply and global sea-level rise. Nature Geos. 2, 488-491.

Chen, Z., et al. (2001) Yangtze River of China: historical analysis of discharge variability and sediment flux. Geomorphology 41(2-3), 77-91. 
Coleman, J.M., Roberts, H.H. \& Stone, G.W. (1998a) Mississippi River Delta: An Overview. J. of Coastal Res. 14(3), 698-716.

Coleman, J.M., Walker, H.J. \& Grabau, W. E. (1998b) Sediment Instability in the Mississippi River Delta. J. of Coastal Res. 14(3), 872-881

Corbett, D.R., McKee, B. \& Duncan, D. (2004) An evaluation of mobile mud dynamics in the Mississippi River deltaic region. Marine Geol. 209(1-4), 91-112.

DeMaster, D.J., et al. (1985) Rates of sediment accumulation and particle reworking based on radiochemical measurements from continental shelf deposits in the East China Sea. Continental Shelf Res. 4(1-2), 143-158.

Fuggle, R. \&Smith, W. (2000) Large dams in water and energy resource development in the People's Republic of China (PRC). Country review paper prepared as an input to the World Commission on Dams, Cape Town, www.dams.org.

Huh, C.-A. \& Su, C.-C. (1999) Sedimentation dynamics in the East China Sea elucidated from ${ }^{210} \mathrm{~Pb},{ }^{137} \mathrm{Cs}$ and ${ }^{239,240} \mathrm{Pu}$. Marine Geol. 160(1-2), 183-196.

Hori, K., et al. (2001) Sedimentary facies and Holocene progradation rates of the Changiiang (Yangtze) delta, China. Geomorphology 41(2-3), 233-248.

Horowitz, A.J. (2009) A quarter century of declining suspended sediment fluxes in the Mississippi River and the effect of the 1993 flood. Hydrol. Processes 24, 13-34.

Hurrell, J.W. (1997) Decade trends in the North Atlantic Oscillation: Regional temperatures and precipitation. Science $269,676-679$.

Kulp, M., et al. (2002) Latest Quaternary stratigraphic framework of the Mississippi River delta region. Gulf Coast Association of Geol. Societies Transactions 52, 573-582.

Liu, J.P., et al. (2006) Sedimentary features of the Yangtze River-derived alongshore clinoform deposit in the East China Sea. Continental Shelf Res. 26, 2141-2156.

Liu, J.P., et al. (2007) Flux and fate of Yangtze River sediment delivered to the East China Sea. Geomorphology 85, $208-224$.

Meade, R.H., Moody, J.A. \& Stevens, H.H. Jr. (1995) Sampling the big rivers. In: Contaminants in the Mississippi River, 1987-92 (Meade, R.H. ed.) US Geological Survey Circular 1133, 40-51. http://pubs.usgs.gov/circ/circ1133.

Meade, R.H. \& Moody, J.A. (2010) Causes for the decline of suspended-sediment discharge in the Mississippi River system, 1940-2007. Hydrol. Processes 24, 35-49, DOI: 10.1002/hyp.7477

Milliman, J.D. \& Meade, R.H. (1983) World-wide delivery of sediment to the oceans. J. of Geol. 91(1), 1-21.

Milliman, J.D. \& Syvitski, J.P.M. (1992) Geomorphic/tectonic control of sediment discharge to the ocean: the importance of small mountainous rivers. J. of Geol. 100(5), 525-544.

Milliman, J.D. \& Farnsworth, F.L. (2011) River Discharge to the Coastal Ocean: A Global Synthesis. Cambridge Press.

Nilsson, C., et al. (2005) Fragmentation and flow regulation of the world's large river systems. Science 308(5720), 405-408.

Roberts, H.H. (1998) Delta switching: early responses to the Atchafalaya river diversion. J. Coastal Res. 14(3), 882-899.

Syvitski, J.P.M., et al. (2005) Impact of humans on the flux of terrestrial sediment to the global coastal ocean. Science 308(5720): 376-380.

Syvitski, J.P.M. \& Milliman, J.D. (2007) Geology, geography and humans battle for dominance over the delivery of sediment to the coastal ocean. J. of Geol. 115, 1-19.

Vörösmarty, C.J., et al. (2003) Anthropogenic sediment retention: major global impact from registered river impoundments. Global and Planetary Change, 39(1-2), 169-190.

Wright, L.D., Sherwood, C.R. \& Sternberg, R.W. (1997) Field measurements of fair weather bottom boundary layer processes and sediment suspension on the Louisiana inner continental shelf. Marine Geol. 140(3-4), 329-345.

Xu, K.H., et al. (2006) Yangtze sediment decline partly from Three Gorges Dam. EOS Trans. AGU, 87(19), 185-190.

$\mathrm{Xu}, \mathrm{K} . \mathrm{H}$., et al. (2007) Climatic and Anthropogenic Impacts on the Water and Sediment Discharge from the Yangtze River (Changiiang), 1950-2005. In: Avijit Gupta (ed.), Large Rivers: Geomorphology and Management. John Wiley \& Sons. 609-626.

Xu, K.H. \& Milliman, J.D. (2009) Seasonal variations of sediment discharge from the Yangtze River before and after impoundment of the Three Gorges Dam. Geomorphology 104(3-4), 276-283.

$\mathrm{Xu}, \mathrm{K} . \mathrm{H}$ et al. (2009) Yangtze- and Taiwan-derived sediments in the Inner Shelf of East China Sea. Continental Shelf Res. 29, 2240-2256. doi:10.1016/j.csr.2009.08.017.

$\mathrm{Xu}, \mathrm{K} . \mathrm{H}$. , et al. (2012) Provenance, structure, and formation of the mud wedge along inner continental shelf of the East China Sea: A synthesis of the Yangtze dispersal system. Marine Geol. 291-294, 176-191.

Yang, S. L. Zhao, Q. Y. \& Belkin, I. M., (2002) Temporal variation in the sediment load of the Yangtze River and the influences of the human activities. J. of Hydrol. 263, 56-71

Yang, S. L., et al. (2005) Impact of dams on Yangtze River sediment supply to the sea and delta wetland response. J. of Geophys. Res.110, F03006, doi:10.1029/2004JF000271.

Yang, S. L., et al. (2010) Temporal variations in water resources in the Yangtze River (Changjiang) over the Industrial Period, based on reconstruction of missing monthly discharges. Water Resour. Res. 46, W10516, doi:10.1029/2009WR008589.

Yang, S.L., et al. (2011) 50,000 dams later: Erosion of the Yangtze River and its delta. Global and Planetary Change, $75,14-20$.

Yang, S.L., et al. (2014) Downstream sedimentary and geomorphic impacts of the Three Gorges Dam on the Yangtze River. Earth-Science Reviews. http://dx.doi.org/10.1016/j.earscirev.2014.07.006.

Yang, Z.S., et al. (2006) Dam impacts on the Changiiang (Yangtze River) sediment discharge to the sea: the past 55 years and after the Three Gorges Dam. Water Resour. Res. 42, W04407, doi:10.1029/2005WR003970. 